\title{
Interactions between tannins and proteins isolated from broad bean seeds (Vicia faba Major) yield soluble and non-soluble complexes
}

\author{
Agnieszka Kosińska • Magdalena Karamać • \\ Kamila Penkacik • Anna Urbalewicz • \\ Ryszard Amarowicz
}

Received: 7 March 2011/Revised: 11 May 2011/Accepted: 22 May 2011/Published online: 10 June 2011

(C) The Author(s) 2011. This article is published with open access at Springerlink.com

\begin{abstract}
The binding of tannin fraction to protein fractions isolated from broad bean seeds was studied by precipitating potential and fluorescence quenching methods. The tannin fraction with high proanthocyanidins content was isolated from broad bean coats. Storage proteins of broad bean, $11 \mathrm{~S}, 7 \mathrm{~S}$, and $2 \mathrm{~S}$, were isolated from broad bean cotyledons and purified. Gelatin, BSA, as well as broad bean $2 \mathrm{~S}$ and $7 \mathrm{~S}$ protein fractions exhibited similar shape of curves illustrating the effect of $\mathrm{pH}$ on protein precipitation and were precipitated by broad bean tannin fraction over the wide range of $\mathrm{pH}$. For pea proteins isolate and $11 \mathrm{~S}$ fraction of broad bean proteins, quite different effect of $\mathrm{pH}$ was observed. The relationships between the amount of proteinpolyphenols complex precipitated and the content of tannin fraction were linear and characterized by high squared correlation coefficients ranging from 0.9613 to 0.9938 . Among the protein fractions isolated from broad bean seeds, the highest precipitating potential was noted for $11 \mathrm{~S}$ fraction, followed by $7 \mathrm{~S}$ and $2 \mathrm{~S}$ fractions and amounted to $1.63,1.34$, and 0.87 , respectively. To characterize the association of proteins with phenolic compounds yielding formation of soluble complexes, fluorescence spectroscopy was applied. Similarly, the most extensive fluorescence quenching was observed in the case of $11 \mathrm{~S}$ protein fraction.
\end{abstract}

\footnotetext{
A. Kosińska (凹) · M. Karamać · K. Penkacik ·

A. Urbalewicz · R. Amarowicz

Division of Food Science, Institute of Animal Reproduction

and Food Research, Polish Academy of Sciences,

Tuwima 10, 10-747 Olsztyn, Poland

e-mail: a.kosinska@pan.olsztyn.pl
}

Keywords Broad bean - Coat tannin fraction . Storage proteins $\cdot$ Phenolics-proteins interaction . Fluorescence quenching

\section{Introduction}

Tannins are widespread in food of plant origin, in particular in fruits, legume seeds, cereal grains, and beverages such as wine, tea, cocoa, cider [1]. A variety of chemical structures are possible within this group of phenolic compounds. Hydrolysable tannins are esters of phenolic acids, such as gallic or ellagic acid, and polyols typically glucose, whereas condensed tannins (proanthocyanidins) are oligomers or polymers of flavan-3-ols linked by carbon-carbon bonds. Recent interest in dietary polyphenols is focused mainly on their health benefits that are ascribed to their ability to act as antioxidants [2,3]. Due to high daily intake of tannins of approximately one gram (highly dependent on dietary habits and preferences), their contribution to overall antioxidants intake in human diet seems to be considerable $[1,4]$. It is believed that tannins may exert their biological effects in two different ways: as an unabsorbable compounds which may produce local effects in the gastrointestinal tract (antioxidant, radical scavenging, antimicrobial, antiviral, antimutagenic, and antinutrient effects) or as absorbable tannins and absorbable metabolites from colonic fermentation of tannins that may produce systemic effects in various organs [5]. Proteins present in food matrix, digestive tract, and bloodstream may significantly influence biological activities of tannins $[2,6]$.

The interactions of phenolic compounds with proteins may result in soluble or insoluble complexes formation [7-10]. The association of polyphenols with proteins is believed to be mainly a surface phenomenon and to take place in two phases 
[11]. Firstly, the polyphenol seeks out preferred sites and regions on the protein, mainly where aromatic and prolyl residues are located. As a result of hydrophobic interactions, docking of polyphenol molecule occurs, and in its vicinity, hydrogen bonds are formed between phenolic hydroxyl groups and protein polar groups (e.g., amino, hydroxyl, and carboxyl groups). Protein surface is being coated with much less hydrophilic layer of polyphenol molecules, which leads to its aggregation and precipitation [12]. Protein-precipitating capacity is a well-known property of tannins and was ascribed to tannins in their first definition formulated by Bate-Smith and Swain and cited by Haslam [13]. Both polyphenol and protein features affect precipitation efficacy. The association depends on molecular size and conformational flexibility of polyphenols as well as on amino acids composition and structure of proteins $[8,14]$. Tannins are believed to act as multidentate ligands, which facilitate protein cross-linking, thus high molecular weight proanthocyanidins should precipitate proteins more effectively; however, it does not apply to all tannins $[11,15]$. In turn, more conformationally rigid ellagitannins precipitate proteins less efficiently than gallotannins $[12,16]$.

Formation of soluble complexes between phenolic compounds and proteins is much more difficult to investigate. Direct determination of the composition of tannin complexes is not possible because tannins interfere with conventional assays of proteins; they may also bind to dialysis membranes or chromatographic media. In recent years, a technique based on fluorescence quenching has been used to this end $[10,17,18]$. Fluorescence spectroscopy is a valuable tool in the investigation of the structure, function, and reactivity of proteins. Wavelength shifts and changes in intensity of the fluorescence emission of tryptophan residues can be used to monitor the environment of these residues in proteins providing information of local interactions [19]. Fluorescence quenching refers to any process that decreases the fluorescence intensity of the fluorophore induced by a variety of molecular interactions with the quencher molecule. There are two basic types of quenching: static and dynamic (collisional). Both types require the molecular contact between the fluorophore and quencher. Collisional quenching involves deactivation of excited state fluorophore with other molecule in solution. The molecules are not chemically altered in the process. The static quenching results from the ground state complex formation between fluorophore and quencher.

Legumes are an important source of nutrient compounds such as protein, starch, dietary fiber, and minerals. Legume seed comprise of three main parts: seed coat, cotyledon, and embryonic axe. The cotyledon contains main reserve substances, proteins and carbohydrates, whereas coat serves as a protective layer for cotyledon and accumulates phenolic compounds [20,21].
To our knowledge to date, carried out studies did not involve examination of interactions between proteins and phenolic compounds isolated from the same legume seeds. A better understanding of those interactions may lead to clearer explanations of the biological activities of tannins. The presented study was conducted on broad bean seeds, which served as a source of both phenolic compounds and proteins. The precipitating capacity of broad bean coat tannin fraction toward broad bean proteins was outlined in a view of its affinity to well-defined proteins: gelatin, bovine serum albumin (BSA), and pea protein isolate. Gelatin is a proline-rich protein, has an open random coil conformation, and is a model for seed prolamins and salivary proline-rich proteins. BSA is a well-characterized model globular protein. Pea protein isolate was used as a reference to legume proteins. Additionally, the affinity of tannic acid, as a commercially available phenolic compound, to proteins was investigated for comparison. Soluble complexes formation was monitored using fluorescence quenching method.

The objective of the study was twofold: (1) to isolate and characterize tannin fraction from broad bean coats and protein fractions from broad bean cotyledons; (2) to characterize interactions between tannins and protein yielding soluble and insoluble complexes.

\section{Materials and methods}

\section{Reagents}

All solvents were of ACS or HPLC grade and were obtained from P.O.Ch. Company (Gliwice, Poland) or Merck (Darmstadt, Germany). Sephadex LH-20, BSA (V fraction), gelatin (B chain), tannic acid, (+)-catechin, vanillin, gallic acid, ferric chloride, and phosphate-buffered saline (PBS) were purchased from Sigma-Aldrich Co. Ltd. (Poznań, Poland). Pea protein isolate "Pisane" was obtained from Coscura Groupe Warcoing (Momalle, Belgium). All other reagents were of at least ACS grade and were acquired from P.O.Ch. Company (Gliwice, Poland). Tannase was kindly supplied by Mr. Nobouyshi Sato of Kikkoman Corporation (Elgin, IL, USA).

\section{Plant material}

Broad bean seeds (Vicia faba Major) of Hangdown white cultivar were purchased in Olzans-CN LLC (Olsztyn, Poland). Coats covering seeds were manually separated from cotyledons, and the proportion between seed coat and cotyledon in the weight of the whole seed was determined. Then, seed coats were subjected to extraction of phenolic compounds, whereas proteins were isolated from cotyledons. 
Isolation and characterization of tannin fraction

\section{Extraction and fractionation}

The broad bean coats were ground in a coffee mill (BSH Bosch \& Siemens Hausgeräte $\mathrm{GmbH}$, Munich, Germany) into fine powder (particle size $<0.8 \mathrm{~mm}$ ). A 60 -g portion of broad bean coat powder was extracted using $80 \%(\mathrm{v} / \mathrm{v})$ aqueous acetone at a solid-to-solvent ratio of 1:8 in a thermostatic shaking water bath (357 Elpan, Lubawa, Poland), at $60^{\circ} \mathrm{C}$ for $15 \mathrm{~min}$. Then, the supernate was filtered through filter paper and the extraction step was repeated twice more. The supernatants were combined, acetone was evaporated using Büchi Rotavapor R-200 (Büchi Labortechnik, Flawil, Switzerland) at $40{ }^{\circ} \mathrm{C}$, and aqueous residue was lyophilized (Lyph Lock 6 freeze dry system, Labconco, Kansas City, MO, USA). One gram of crude extract of broad bean coat phenolic compounds was suspended in $10 \mathrm{~mL}$ of $96 \%$ (v/v) ethanol and applied onto a chromatographic column $(30 \mathrm{~mm}$ i.d. $\times 230 \mathrm{~mm} l)$ packed with lipophilic Sephadex LH-20 gel (SigmaAldrich). Firstly, low molecular weight phenolics were eluted gravimetrically using $96 \%(\mathrm{v} / \mathrm{v})$ ethanol, and then, solvent was changed over to $50 \%(\mathrm{v} / \mathrm{v})$ acetone in order to elute tannins. Acetone from tannin fraction was evaporated, and remaining water was lyophilized.

\section{Total phenolics content (TPC)}

The TPC of broad bean coat crude extract and tannin fraction was determined using colorimetric assay with Folin-Ciocalteu phenol reagent according to Naczk and Shahidi [22]. Briefly, $0.25 \mathrm{~mL}$ of methanolic solution of extract or tannin fraction was mixed with $0.25 \mathrm{~mL}$ of Folin-Ciocalteu reagent (diluted 1:1 with distilled water), and then, $0.5 \mathrm{~mL}$ of sodium carbonate saturated solution and $4 \mathrm{~mL}$ of water was added, and mixture was vortexed thoroughly (Genie2, Scientific Industries, Bohemia, NY, USA). Absorbance at $725 \mathrm{~nm}$ after $30 \mathrm{~min}$ color development was measured with Beckman DU-7500 spectrophotometer (Beckman Coulter, Fullerton, CA, USA) with prior centrifugation of samples. TPC was expressed as mg (+)catechin equivalents per gram of extract or fraction from triplicate measurements.

\section{Condensed tannins content}

The method of Price et al. [23] was employed to determine condensed tannins content of crude extract and tannin fraction. Methanolic solutions of samples $(1 \mathrm{~mL})$ at a concentration of $0.25 \mathrm{mg} / \mathrm{mL}$ were mixed with $5 \mathrm{~mL}$ of vanillin reagent (obtained by dissolving of $0.5 \mathrm{~g}$ vanillin in $100 \mathrm{~mL} \mathrm{4 \%} \mathrm{(v/v)} \mathrm{concentrated} \mathrm{hydrochloric} \mathrm{acid).}$
The absorbance of the mixture was measured after a 20 -min period of reaction development at $500 \mathrm{~nm}$ using Beckman DU-7500 spectrophotometer. Due to the lack of appropriate standard for this assay, the results were expressed as absorbance units per $\mathrm{g}$ of sample $\left(A_{500} / \mathrm{g}\right)$.

\section{Hydrolysable tannin content}

In order to estimate hydrolysable tannins, content of broad bean coat tannin fraction was subjected to enzymatic hydrolysis with tannase [24]. Four milliliters of tannin fraction solution in citric buffer $(50 \mathrm{mM}, \mathrm{pH} 5.5)$, at a concentration of $4 \mathrm{mg} / \mathrm{mL}$, was mixed with $1 \mathrm{~mL}$ of tannase solution $(50 \mu \mathrm{g}, 50,000 \mathrm{U} / \mathrm{g}$; in the same buffer). Samples were incubated at $30{ }^{\circ} \mathrm{C}$ for $15 \mathrm{~min}$, and then, $\mathrm{pH}$ was adjusted to 2 with $2 \mathrm{M} \mathrm{HCl}$ solution. Gallic acid liberated during hydrolysis was extracted into diethyl ether, solvent was evaporated, and solid residue was dissolved in $2 \mathrm{~mL}$ of methanol. The parallel control sample without tannase addition was incubated and extracted. Gallic acid content in the hydrolyzed and control samples was determined using a Shimadzu HPLC system (Shimadzu Co., Kyoto, Japan) consisting of $\mathrm{LC} 10 \mathrm{AD}_{\mathrm{Vp}}$ pump, SPDM10A $A_{V p}$ photodiode detector, SCL- $10 A_{V p}$ controller. Twenty microliters of methanolic solutions of sample was filtered through a $0.45-\mu \mathrm{m}$ nylon filter and injected onto LiChrospher $100 \mathrm{RP}-18$ column $(4.6 \times 250 \mathrm{~mm}, 5 \mu \mathrm{m}$; Merck, Darmstadt, Germany). The chromatographic separation was performed in isocratic system of a mobile phase consisting of water/acetonitrile/acetic acid (88:10:2; v/v/v) with a flow rate of $1 \mathrm{~mL} / \mathrm{min}$. Gallic acid was identified and quantified with reference to gallic acid standard solution. Then, the difference in the content of gallic acid in the tannin fraction after tannase hydrolysis and in non-hydrolyzed sample was calculated.

Isolation and characterization of protein fractions

\section{Extraction and fractionation}

Ground broad bean cotyledons $(10 \mathrm{~g})$ were extracted with $100 \mathrm{~mL}$ of $20 \mathrm{mM}$ phosphate buffer at $\mathrm{pH} 7.5$ containing $1 \mathrm{M} \mathrm{NaCl}$ at room temperature for $2 \mathrm{~h}$. Then, the suspension was centrifuged for $30 \mathrm{~min}$ at $5,000 \times g$ and at a temperature of $4{ }^{\circ} \mathrm{C}$ using MPW 350R centrifuge (MPW Med. Instruments, Warsaw, Poland). Precipitate was discarded, and $500 \mathrm{~mL}$ of deionized water was added to the supernate, and after $1 \mathrm{~h}$, the suspension was centrifuged $(5,000 \times g, 30 \mathrm{~min})$. The precipitate obtained in that manner contained globulins, whereas albumins were present in the supernate. The globulins precipitate was dissolved in phosphate buffer and precipitated with $35 \%$ saturated ammonium sulfate, whereas to precipitate albumins from 
the supernate, $80 \%$ saturated ammonium sulfate was added and suspensions were centrifuged. Both globulins and albumins precipitates were dialyzed against deionized water using dialysis tubings (Sigma-Aldrich) with molecular cutoff of $12,400 \mathrm{Da}$ at $4{ }^{\circ} \mathrm{C}$ for $48 \mathrm{~h}$. Then, the protein extracts were lyophilized and chromatographically purified. Protein extract was dissolved in the mobile phase (50 mM phosphate buffer pH 6.9 containing $0.15 \mathrm{M} \mathrm{NaCl}$ and $0.1 \%$ sodium azide) at a concentration of $25 \mathrm{mg} / \mathrm{mL}$ and loaded onto the column $(26 \mathrm{~mm}$ i.d. $\times 100 \mathrm{~cm} l)$ filled with Sephadex G-200 superfine gel (Sigma-Aldrich). The mobile phase was delivered to the column at a flow rate of $0.5 \mathrm{~mL} / \mathrm{min}$ by peristaltic pump (Unipan 315, Warsaw, Poland). The fractions of $5 \mathrm{~mL}$ volume were collected using Redi Frac fraction collector (GE Healthcare). The elute was monitored at 220 and $280 \mathrm{~nm}$ with Beckman DU-7500 spectrophotometer. Once the chromatogram of protein separation was prepared, three individual fractions (I, II, III) were pooled and dialyzed. In order to estimate molecular weight of individual fractions, the column was calibrated with molecular weight marker consisting of the following: ferritin, aldolase, bovine serum albumin, chymotripsinogen A, cytochrome C (Sigma-Aldrich) with molecular weights of 440,000, 270,000, 67,000, 25,000, and 12,400 Da, respectively. The major fractions prepared according to above-mentioned procedure in five replicate processes were pooled once SDS-PAGE analysis confirmed the similarity of protein composition in the five preparations.

\section{Sodium dodecyl sulfate polyacrylamide gel electrophoresis (SDS-PAGE)}

The molecular weight distribution of broad bean protein fractions was analyzed in Laemmli buffer system according to Hames [25] using Mini PROTEAN Tetra cell system (BioRad, Hercules, CA, USA). Fractions were dissolved in $62.5 \mathrm{mM}$ Tris-HCl buffer at $\mathrm{pH} 6.8$ with $2 \% \mathrm{SDS}, 5 \% \beta$ mercaptoethanol, $10 \%$ glycerol, and $0.002 \%$ bromophenol blue and heated for $5 \mathrm{~min}$ in boiling water. Cooled samples $(20 \mu \mathrm{g})$ were loaded into each well of $12.5 \%$ polyacrylamide gel and separation was performed at $25 \mathrm{~mA}$. Low Range Sigma Molecular Marker 6,500-66,000 Da (SigmaAldrich) was used to estimate molecular weights of individual protein subunits.

\section{Protein content}

Bradford method [26] was employed to assess protein content of isolated fractions. The obtained results of protein content were utilized to calculate precipitating capacity per gram of protein in protein fraction.
Binding studies

\section{Precipitating potential assay}

The ability of broad bean coat tannins to precipitate isolated broad bean protein fractions as well as model proteins, i.e., BSA, gelatin, and pea proteins, was investigated employing the procedure described by Hagerman and Butler [27] with some modifications. Firstly, the effect of $\mathrm{pH}$ on the formation of phenolic protein insoluble complexes was investigated. Phenolic compounds solutions were prepared in $50 \%$ aqueous ethanol at a concentration of $1 \mathrm{mg} / \mathrm{mL}$, whereas proteins were dissolved in McIvaine buffer at $\mathrm{pH}$ in the range from 2 to 8 and at a concentration of $1 \mathrm{mg} / \mathrm{mL}$. The procedure of Hagerman and Butler [27] was scaled down: $200 \mu \mathrm{L}$ of phenolic compounds solution was added to $400 \mu \mathrm{L}$ of protein solution and mixed well. After $15 \mathrm{~min}$ of quiescent period, the reaction mixture was centrifuged at $4,000 \times g$ for $15 \mathrm{~min}$ (MPW Med. Instruments, Warsaw, Poland). The supernate was discarded, and the surface of the pellet and the walls of the tubes were rinsed with buffer to remove remained unbound phenolics. Then, the pellet was dissolved in $800 \mu \mathrm{L}$ of sodium dodecyl sulfate (SDS)-triethanolamine solution (1\% SDS and $5 \%$ triethanolamine), and $200 \mu \mathrm{L}$ of $0.01 \mathrm{M}$ ferric chloride solution (in $0.01 \mathrm{M} \mathrm{HCl}$ ) was added. The reaction was developed for $15 \mathrm{~min}$, and then, the absorbance at $510 \mathrm{~nm}$ was read against a reagent blank consisting of SDS-triethanolamine and ferric chloride mixture. Once the optimal $\mathrm{pH}$ for phenolic compounds-proteins complex formation was determined, the effect of phenolic compounds concentration on complex formation at optimal $\mathrm{pH}$ was assessed. The phenolic compound solutions at a concentration in the range from 0.1 to $3.0 \mathrm{mg} / \mathrm{mL}$ were mixed with individual proteins, and the amount of complexes formed was determined. The plot of phenolic compounds concentration expressed as mg catechin equivalents per mg of protein versus $A_{510}$ was prepared. The protein precipitation potential was expressed as the linear regression coefficient and presented in the comparison with values obtained for tannic acid.

\section{Fluorescence quenching method}

The interactions between tannin fraction and protein fraction yielding soluble complexes were investigated using fluorescence quenching method [17]. The fluorescence quenching involves a reduction in fluorophore fluorescence in the presence of quencher. All measurements were taken in quartz cuvette $(1.0 \times 1.0 \times 4.0 \mathrm{~cm})$ using Perkin Elmer LS 50B fluorescence spectrometer (Beaconsfield, Great Britain). Fluorescence emission spectra were recorded in the wavelength range of $285-500 \mathrm{~nm}$ by exciting protein at 
Table 1 Yield of isolation, total phenolic content, and condensed tannin content of broad bean coat preparations

\begin{tabular}{llll}
\hline & Isolation yield $(\%)$ & $\begin{array}{l}\text { Total phenolic content } \\
(\mathrm{mg}(+) \text {-catechin equivalents/g) }\end{array}$ & $\begin{array}{l}\text { Condensed tannins } \\
\text { content }\left(A_{500} / \mathrm{g}\right)\end{array}$ \\
\hline Crude extract $^{\mathrm{a}}$ & $3.98 \pm 0.23$ & $540 \pm 10$ & $1,210 \pm 30$ \\
Tannin fraction $^{\mathrm{b}}$ & $2.50 \pm 0.17$ & $740 \pm 21$ & $1,490 \pm 20$ \\
\hline
\end{tabular}

${ }^{\text {a }}$ Obtained using $80 \%$ acetone

${ }^{\mathrm{b}}$ Eluted with 50\% acetone from Sephadex LH20 column

excitation wavelength $\left(\lambda_{\mathrm{ex}}\right)$ of $282 \mathrm{~nm}$. The slit width for both excitation and emission was set to $5 \mathrm{~nm}$. To determine the linear concentration range for protein fluorescence, a series of protein fractions and BSA solutions with increasing concentration were prepared in PBS buffer of $\mathrm{pH}$ 7.4. Suitable protein concentration was chosen for fluorescence quenching experiments. To $3 \mathrm{~mL}$ of protein solution, portions of $6 \mu \mathrm{L}$ of tannin fraction solution $(1 \mathrm{mg} / \mathrm{mL})$ were added and the mixture was shaken. The changes of fluorescence intensity were measured within $30 \mathrm{~s}$ after addition. All fluorescence readings were corrected for protein dilution effect. The titration was performed in four replications. In order to avoid artifact quenching, the broad bean tannin fraction solution was checked for its intrinsic fluorescence. All measurements were taken at room temperature.

\section{Statistical analysis}

The results were expressed as mean values \pm standard deviation from at least three replicates. The statistical analyses of data (linear regression analysis, standard errors of slopes) were performed using GraphPad Prism 5 (GraphPad Software Inc., San Diego, CA, USA). The determination of the regression coefficient (slope) values was based on the analysis of experimental data involving the precipitation of tannin-protein complexes at a minimum of five different tannin concentrations in the assay mixture.

\section{Results and discussion}

Phenolic compounds are concentrated mainly in outer anatomical parts of plants due to their protecting function against pathogens. The legume coat constitutes minor part of whole seed; nevertheless, the majority of phenolic compounds present in legumes were demonstrated to be located in the testa. The broad bean coat separated from seeds investigated in the present study represented $14.1 \%$ of the whole seed weight, whereas legume seeds coat, on average, accounted for $10 \%$ of the whole seed [20].

The aqueous acetone is commonly employed to efficiently extract phenolic compounds from legume seeds
[28-30]. In our study, the obtained extract was then fractionated on Sephadex LH-20 gel to separate tannin fraction from low molecular weight compounds. The results of isolation yield, total phenolics content, and condensed tannins content of crude extract and tannin fraction of broad bean coats were reported in Table 1. Tannin fraction of broad bean coat constituted $63 \%$ of crude extract. The fraction was observed to possess higher total phenolic content than the crude extract, 740 and $540 \mathrm{mg}(+)$-catechin equivalents per gram of preparation, respectively. It should be also pointed out that the content of phenolic compounds in broad bean coat is a dozen or so times higher in comparison with broad bean cotyledons [31]. The tannin fraction was characterized by very high content of condensed tannins determined with vanillin $/ \mathrm{HCl}$ reagent, which amounted to $1,490 A_{500}$ units per gram of fraction. Literature data rarely report on equally high values except to Naczk et al. [32], who noted 1,694 $A_{500}$ units/g of beach pea tannin fraction, and Arfan et al. [33], who found 1,321 $A_{500}$ units/g of Mallotus philippinensis bark tannin fraction. Condensed tannins were previously reported as predominant compounds of other legume seeds coats such as common bean seed [34], soybean seed [30], and lentil seed [21].

In order to find out whether tannin fraction analyzed in our study contained also hydrolysable tannins, the tannase hydrolysis was carried out. Since only $88 \mu \mathrm{g}$ of gallic acid was liberated from $1 \mathrm{~g}$ of tannin fraction, it could be stated that hydrolysable tannins were not detected in broad bean tannin fraction.

The protein extraction preceded isolation and purification of three major fractions of broad bean storage proteins. In order to avoid phenolic compound-protein complex formation during isolation process, the procedure applied did not involve precipitation at isoelectric point or extraction at high $\mathrm{pH}$ value. Instead, extraction with neutral buffers and chromatographic purification were employed. The molecular weight distribution of isolated fractions was analyzed by the SDS-PAGE method to identify three individual fractions of broad bean proteins. The obtained electrophoregram was depicted in Fig. 1. Four bands were detected in the fraction I, whose molecular weights were estimated to amount to: $33,29,22$, and $20 \mathrm{kDa}$, with the 


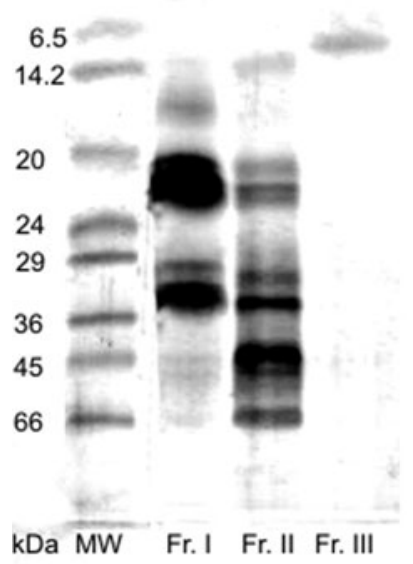

Fig. 1 Electrophoretic profile of broad bean protein fractions, $M W$ molecular weight standard

highest intensity of bands corresponding to molecular weight of 33 and $22 \mathrm{kDa}$. Literature data report on the existence of two major subunits of legumin-like protein with similar molecular weights $[35,36]$. SDS-PAGE of fraction II revealed the presence of five subunits with molecular weights of $66,45,34,23$, and $14 \mathrm{kDa}$. Scholz et al. [37] showed five bands corresponding to molecular weights of $50,35,31,19$, and $14 \mathrm{kDa}$ in the vicilin-like component of broad bean. In turn, one band was observed in the fraction III corresponding to molecular weight of $12.8 \mathrm{kDa}$. On the basis of the above-described molecular weight distribution of individual fractions and determination of their molecular weights by SE-HPLC analysis (data not shown), it was confirmed that isolated fractions I, II, and III constitute three major broad bean storage proteins: legumin-like globulins (11S), vicilin-like globulins (7S), and albumins (2S), respectively.

The protein precipitation assay was developed by Hagerman and Butler [27] for the quantification of tannins in plant material. In the present study, the precipitating capacity of broad bean tannin fraction toward protein fractions isolated from broad bean cotyledons, and model proteins such as BSA, gelatin and commercially available pea proteins isolate was determined. For comparison, precipitating capacity of tannic acid toward the same proteins was assessed. As a measure of protein precipitating capacity, the regression coefficient (slopes) of linear regressions fitted to measurements taken at several different concentrations was calculated as adapted from Naczk et al. $[9,32,38]$. The evaluation of precipitating potential was preceded by the determination of the optimum $\mathrm{pH}$ for individual proteins and protein fractions. Figure 2 illustrates the effect of $\mathrm{pH}$ on the formation of insoluble protein-polyphenol complexes. The interactions between tannins and proteins were demonstrated to be affected by
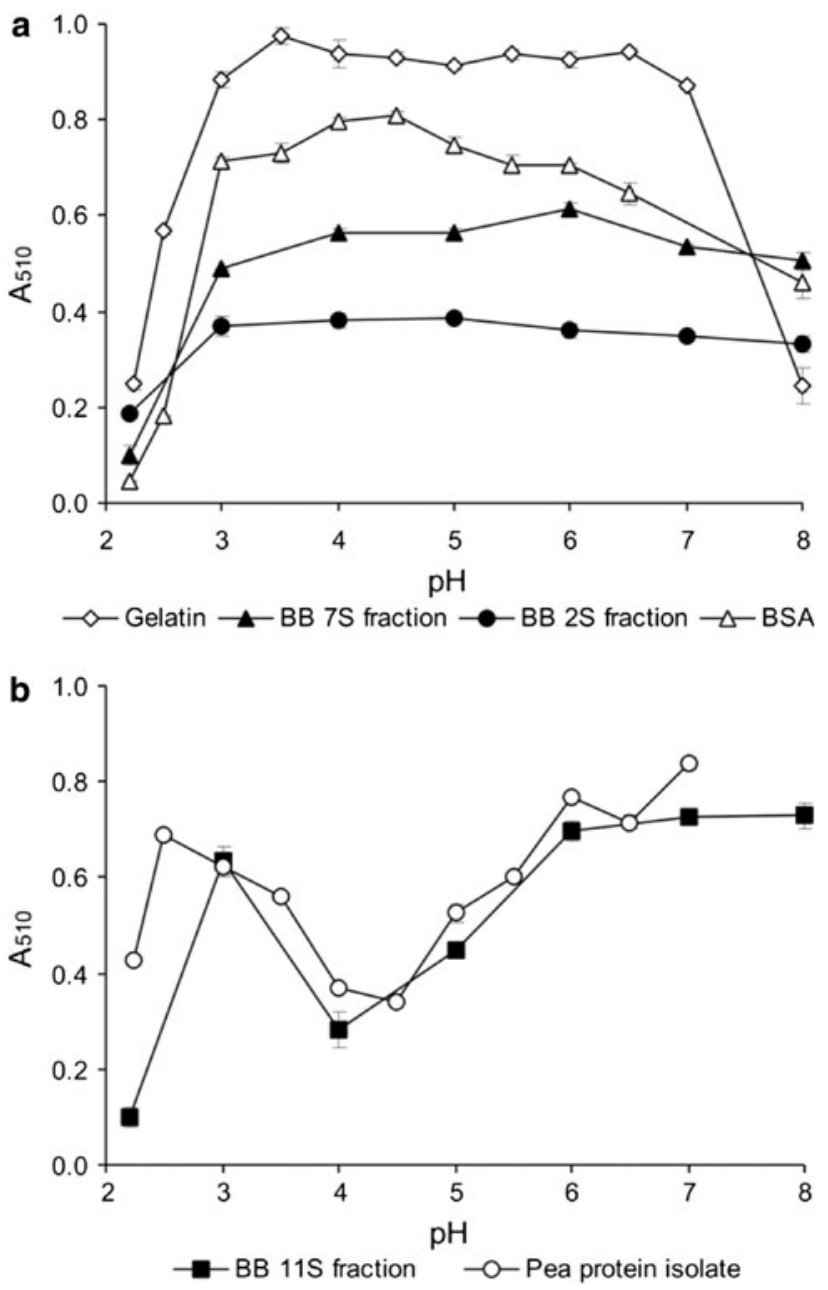

Fig. 2 Effect of $\mathrm{pH}$ on formation of insoluble complexes between broad bean coat tannin fraction and proteins: gelatin, bovine serum albumin $(B S A)$, broad bean $(B B) 7 \mathrm{~S}$ and $2 \mathrm{~S}$ fractions-a; pea protein isolate and $\mathrm{BB} 11 \mathrm{~S}$ fraction- $\mathbf{b}$

$\mathrm{pH}$. Gelatin, BSA, as well as broad bean $2 \mathrm{~S}$ and $7 \mathrm{~S}$ protein fractions exhibited similar shape of curves illustrating the effect of $\mathrm{pH}$ on protein precipitation (Fig. 2a). Gelatin was precipitated by broad bean tannin fraction over a wide range of $\mathrm{pH}(3-7)$. Similarly, $7 \mathrm{~S}$ and $2 \mathrm{~S}$ fractions were efficiently precipitated at $\mathrm{pH} 3-8$. In the case of BSA, the maximum precipitation point was at $\mathrm{pH} 4.5$. Hagerman and Butler [27] suggested that the strongest protein-phenolic compounds interactions occurred at $\mathrm{pH}$ close to isoelectric point of protein (in the case of BSA 4.9). Naczk et al. [32, 38] examined broad range of phenolic compound extracts and fractions from various plant material and noted optimal $\mathrm{pH}$ for BSA precipitation around 4-4.5. The authors did not report on significant changes of optimum $\mathrm{pH}$ depending on source of phenolic compounds. The shape of the curves illustrating the dependency between $\mathrm{pH}$ and precipitating capacity for pea proteins isolate and $11 \mathrm{~S}$ fraction of broad bean proteins was quite different than for other proteins 

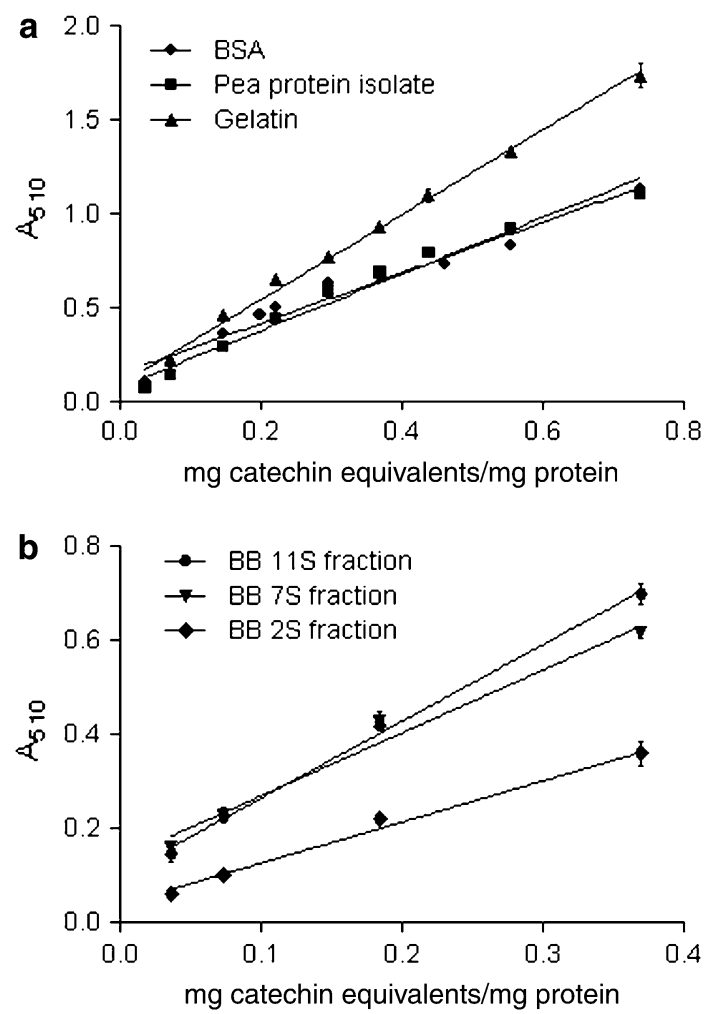

Fig. 3 Relationship between the amount of precipitating proteinphenolic compounds complex formed and the amount of tannin fraction added for model proteins a: BSA $-y=1.34 x+0.14, R^{2}=0.9613$; pea protein isolate $-y=1.50 x+0.07, R^{2}=0.9732$; gelatin $y=2.26 x+0.09, R^{2}=0.9927$ and broad bean $(B B)$ protein fractions b: $11 \mathrm{~S}-y=1.63 x+0.10, R^{2}=0.9938 ; 7 \mathrm{~S}-y=1.34 x+0.13$, $R^{2}=0.9759 ; 2 \mathrm{~S}-y=0.87 x+0.04, R^{2}=0.9684$

examined (Fig. 2b). High $A_{510}$ values were noted at $\mathrm{pH}$ 2.5-3.5 and 5.5-7.0, whereas very low values at $\mathrm{pH}$ 4.0-4.5 were observed. Taking into consideration the lowest solubility of pea protein isolate at $\mathrm{pH}$ in the range of 4-6 reported by Soral-Śmietana et al. [39], it can be concluded that the association of that protein with tannin fraction does not follow the rule of the highest affinity at protein isoelectric point formulated by Hagerman and Butler [16]. The similarity of $\mathrm{pH}$ dependency precipitation pattern between pea protein isolate and broad bean $11 \mathrm{~S}$ protein can be explained by the fact that $11 \mathrm{~S}$ pea protein is probably the dominant constituent of the isolate [40].

The relationship between the amount of protein-polyphenol complex precipitated $\left(A_{510}\right)$ and the content of tannin fraction (expressed as catechin equivalents/mg of protein) in the mixture was investigated at optimal $\mathrm{pH}$ for each protein. The curves illustrating that dependency were depicted in Fig. 3. The linear relationships were noted for each model protein (in the range of 0.04-0.74 $\mathrm{mg}$ catechin equivalents/mg of protein added-Fig. 3a) and protein fraction tested (in the range of $0.04-0.37 \mathrm{mg}$ catechin

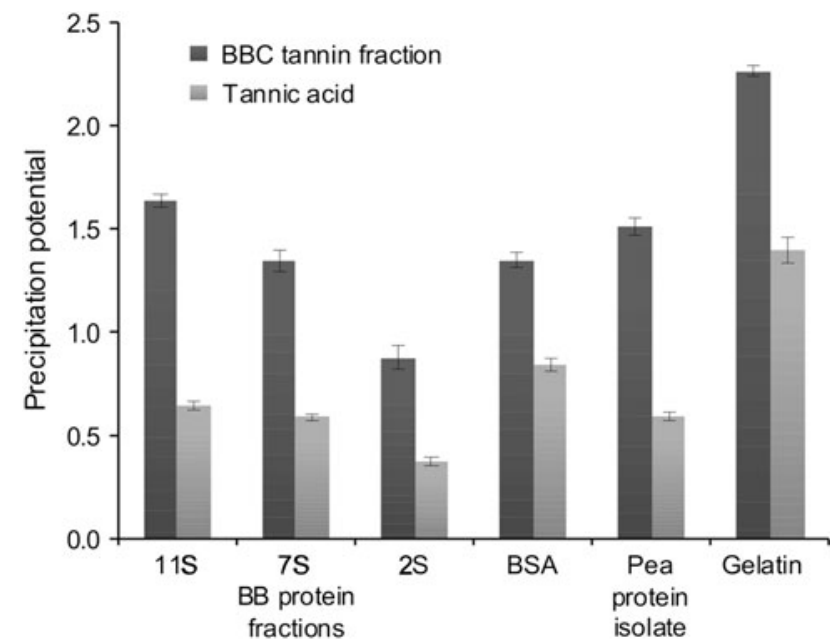

Fig. 4 Protein precipitating potential of broad bean coat (BBC) tannin fraction and tannic acid; $11 \mathrm{~S}, 7 \mathrm{~S}, 2 \mathrm{~S}$ broad bean protein fractions; $B S A$ bovine serum albumin

equivalents/mg of protein added-Fig. 3b). The curves were characterized by high squared correlation coefficients, which ranged from 0.9613 for BSA and 0.9938 for $11 \mathrm{~S}$ broad bean protein fraction. The slope values of the titration curves reflected the protein precipitating potential of polyphenolic [9]. The broad bean tannin fraction demonstrated the highest affinity to gelatin and amounted to 2.26. It is not surprising taking into consideration "open structure" of that protein. The precipitating potential of tannin fraction toward pea protein isolate amounted to 1.50 and was lower than versus gelatin and higher versus than BSA. Among protein fraction isolated from broad bean seeds, the highest precipitating potential was noted for $11 \mathrm{~S}$ fraction, followed by $7 \mathrm{~S}$ and $2 \mathrm{~S}$ fractions and amounted to 1.63 , 1.34 , and 0.87 , respectively. It means that the affinity to tannins decreased along with decreasing molecular weight of broad bean proteins. It is quite surprising that $11 \mathrm{~S}$ protein fraction of broad bean, which is characterized by compact structure exhibited comparatively high affinity to tannins. The presence of higher number of binding sites in protein implements its higher affinity to tannins; however, the conclusion that the higher molecular weight of proteins denotes its higher affinity would be an oversimplification. It can be assumed that binding sites of $11 \mathrm{~S}$ broad bean proteins are easily accessible for tannins. The lowest precipitating potential of broad bean fraction was noted for broad bean $2 \mathrm{~S}$ albumin. Low affinity of phenolic compounds to proteins with molecular weight lower than $20 \mathrm{kDa}$ was also reported by Hagerman and Butler [16]. It is worth noting that pea protein isolate and $11 \mathrm{~S}$ fraction of broad bean proteins again exhibited similarity in term of precipitating potential, namely 1.50 and 1.63 , respectively.

The protein precipitating potential of broad bean tannin fraction compared with that of tannic acid was depicted in 

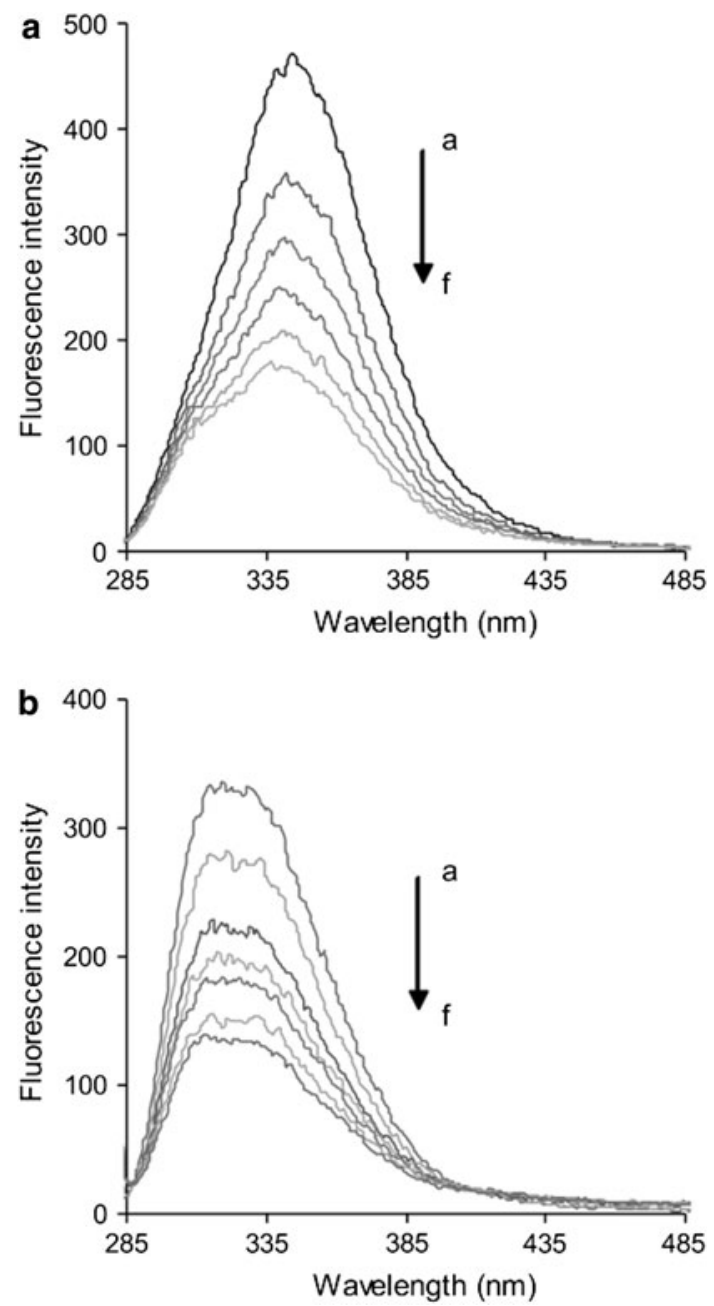

Fig. 5 Fluorescence emission spectra (at $\lambda_{\mathrm{ex}}=282 \mathrm{~nm}$ ) of BSA (a) and broad bean protein fraction $11 \mathrm{~S}$ (b) in the presence of increasing concentration of tannin fraction $(0,15,30,60,90$, and $120 \mu \mathrm{g}$ catechin equivalents/mg protein from a to f) in phosphate buffer at $\mathrm{pH} 7.4$

the Fig. 4. For all proteins tested, the affinity of tannic acid to proteins was lower in comparison with broad bean tannin fraction. Literature data report that hydrolysable tannins generally exhibit higher precipitating potential than proanthocyanidins $[11,13]$. In the present study, we noted higher precipitating potential of broad bean tannin fraction in comparison with that of tannic acid. It may indicate that the fraction comprised of high molecular weight tannin molecules since larger molecules of tannins can occupy a greater number of binding sites in the protein and evoke greater aggregation and precipitation.

Fluorescence quenching method was applied in order to check whether interactions between broad bean tannins and protein fractions lead to formation of soluble complexes. The method of investigating into protein-phenol interactions on the basis of tryptophan quenching was reported to be useful to study the interactions of complexed food

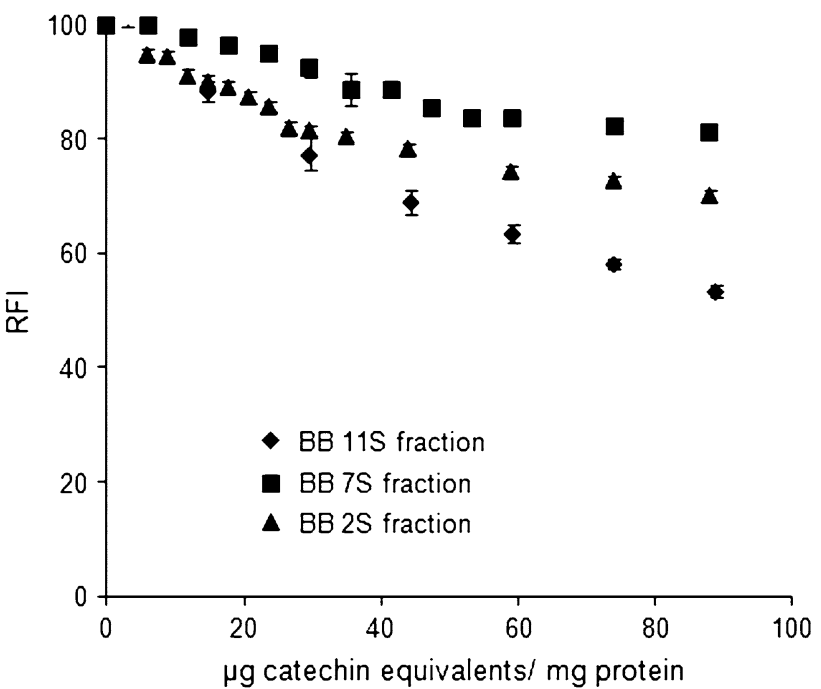

Fig. 6 Tryptophan fluorescence quenching of broad bean (BB) protein fractions plotted as relative fluorescence intensity $\mathrm{RFI}=\left(F_{0} / F \times 100\right)$ versus tannin fraction concentration expressed as $\mu \mathrm{g}$ catechin equivalents/mg protein. Fluorescence emission intensity was recorded at $\lambda_{\mathrm{ex}}=282 \mathrm{~nm}$ and $\lambda_{\mathrm{em}}=320 \mathrm{~nm}(\mathrm{BB} 11 \mathrm{~S}$ fraction), $\lambda_{\mathrm{em}}=329 \mathrm{~nm}$ (BB $7 \mathrm{~S}$ fraction), $\lambda_{\mathrm{em}}=338 \mathrm{~nm}($ BB $2 \mathrm{~S}$ fraction)

matrices. Measurements of intrinsic fluorescence of protein give information about the molecular environment in the vicinity of tryptophan. BSA showed a typical fluorescence spectrum with an emission maximum $\left(\lambda_{\mathrm{em} \text { max }}\right)$ at $344 \mathrm{~nm}$ (Fig. 5), which is in accordance with the literature data [17, 18]. The structure of BSA is well defined; it contains two tryptophan residues located in separate domains [19]. The maxima of fluorescence emission observed for broad bean protein fractions $11 \mathrm{~S}, 7 \mathrm{~S}$, and $2 \mathrm{~S}$ accounted to 320,329 , and $338 \mathrm{~nm}$, respectively. They are blue-shifted with respect to $\lambda_{\mathrm{em} \max }$ of free tryptophan $(\sim 350 \mathrm{~nm})$. The emission maximum at $320 \mathrm{~nm}$ recorded in the case of $11 \mathrm{~S}$ suggests that tryptophan residues are buried in the hydrophobic core of protein, and in $2 \mathrm{~S}\left(\lambda_{\mathrm{em}} \max\right.$ at higher wavelength), they are located on the surface of the protein. Changes in the emission spectra of protein may occur in response to protein conformational transitions, subunit association, ligand binding, or denaturation. The addition of broad bean tannin fraction to protein solution caused a reduction in protein fluorescence intensity (Fig. 5). At the same time, it did not considerably alter the shape of protein spectra; therefore, it was assumed that interactions between phenolic compounds and protein fraction did not significantly change the proteins structure [17]. It is important to keep in mind that phenolic compounds absorb energy at both protein excitation and emission wavelength. Consequently, an inner filtering effect occurs, which intensifies with increasing phenolic compounds concentration. To overcome this effect, the fluorescence intensity was 
corrected according to Beer-Lambert's law using equation [19]:

$F_{\text {corr }}=F_{\text {obs }} 10^{\frac{\left(A_{1}+A_{2}\right)}{2}}$

where $F_{\text {obs }}$ and $F_{\text {corr }}$ are the observed and corrected fluorescence intensities, respectively, and $A_{1}$ and $A_{2}$ are the absorbances at the excitation and emission wavelengths, respectively. Figure 6 presents tryptophan fluorescence quenching of broad bean $(\mathrm{BB})$ protein fractions plotted as RFI (relative fluorescence intensity) $\left(F_{0} / F_{\text {corr }} \times\right.$ 100) versus tannin fraction concentration, where $F_{0}$ is initial fluorescence without quencher added. The content of tannin fraction in binding mixture was expressed as $\mu \mathrm{g}$ $(+)$-catechin equivalents per $\mathrm{mg}$ of protein, from calculations based on total phenolic content in tannin fraction. The strongest quenching of tryptophan was observed in the case of broad bean $11 \mathrm{~S}$ fraction. The calculated relative fluorescence intensity amounted to $53 \%$, whereas for $2 \mathrm{~S}$ and $7 \mathrm{~S}$ protein fractions to 70 and $81 \%$, respectively. It may be assumed that coat tannin fraction binds to high molecular weight storage proteins yielding soluble complexes to a greater extent than it can be observed for $2 \mathrm{~S}$ and $7 \mathrm{~S}$ protein fraction. Similar effect was noted for nonsoluble complexes formation. It should be pointed out that the ratio of tannin fraction per protein was lower in the fluorescence quenching study than in the precipitating assay.

\section{Conclusions}

It may be assumed that the initial binding between tannins and proteins yields soluble complexes which upon subsequent cross-linking are transformed into insoluble precipitates. Strong interactions between broad bean protein fraction and tannins yielding insoluble complexes were noted at high ratio between phenolic compounds and proteins. The precipitating potential noted for broad bean high molecular weight proteins was slightly lower than that of gelatin, known for its high affinity to polyphenols. For all proteins tested, the precipitating potential of broad bean tannins was higher than that of tannic acid. The extent of precipitation was dependent on $\mathrm{pH}$. This phenomenon should be taken into consideration during designing of technological processes. It might also be of vital importance for the biological activities of tannins.

Acknowledgments We would like to acknowledge a kind gift of tannase samples from Mr. Nobouyshi Sato of Kikkoman Corporation (Elgin, IL, USA).

Conflict of interest The authors declare that they have no conflict of interest.
Open Access This article is distributed under the terms of the Creative Commons Attribution Noncommercial License which permits any noncommercial use, distribution, and reproduction in any medium, provided the original author(s) and source are credited.

\section{References}

1. Santos-Buelga C, Scalbert A (2000) Proanthocyanidins and tannin-like compounds-nature, occurrence, dietary intake and effects on nutrition and health. J Sci Food Agric 80:1094-1117

2. Hagerman AE, Riedl KM, Jones GA, Sovik KN, Ritchard NT, Hartzfeld PW, Riechel TL (1998) High molecular weight plant polyphenolics (tannins) as biological antioxidants. J Agric Food Chem 46:1887-1892

3. Rice-Evans CA, Miller NJ, Paganga G (1997) Antioxidant properties of phenolic compounds. Trends Plant Sci 2:152-159

4. Scalbert A, Williamson G (2000) Dietary intake and bioavailibility of polyphenols. J Nutr 130:2073-2085

5. Serrano J, Puupponen-Pimiä R, Dauer A, Aura AM, Saura-Calixto F (2009) Tannins: Current knowledge of food sources, intake, bioavailability and biological effects. Mol Nutr Food Res 53:310-329

6. Papadopoulou A, Frazier RA (2004) Characterization of proteinpolyphenol interactions. Trends Food Sci Technol 15:186-190

7. Calderon P, Van Buren J, Robinson WB (1968) Factors influencing the formation of precipitates and hazes by gelatin and condensed and hydrolysable tannins. J Agric Food Chem $16: 479-482$

8. Hagerman AE (1989) Chemistry of tannin-protein complexation. In: Hemingway RW, Karchesy JJ (eds) Chemistry and significance of condensed tannins. Plenum Publishing Corp, New York, pp 323-333

9. Naczk M, Grant S, Zadernowski R, Barre E (2006) Protein precipitating capacity of phenolics of wild blueberry leaves and fruits. Food Chem 96:640-647

10. Prigent SVE, Gruppen H, Visser AJWG, van Koningsveld GA, de Jong GAH, Voragen AGJ (2003) Effects of non-covalent interactions with 5-O-caffeoylquinic acid (chlorogenic acid) on the heat denaturation and solubility of globular proteins. J Agric Food Chem 51:5088-5095

11. Spencer CM, Cai Y, Martin R, Gaffney SH, Goulding PN, Magnolato D, Lilley TH, Haslam E (1988) Polyphenol complexation-some thoughts and observations. Phytochemistry 27:2397-2409

12. Deaville ER, Green RJ, Mueller-Harvey I, Willoughby I, Frazier RA (2007) Hydrolyzable tannin structures influence relative globular and random coil protein binding strengths. J Agric Food Chem 55:4554-4561

13. Haslam E (1996) Natural polyphenols (vegetable tannins) as drugs: possible modes of action. J Nat Prod 59:205-215

14. Charlton AJ, Baxter NJ, Khan ML, Moir AJG, Haslam E, Davies AP, Williamson MP (2002) Polyphenol/peptide binding and precipitation. J Agric Food Chem 50:1593-1601

15. Frazier RA, Deaville ER, Green RJ, Stringano E, Willoughby I, Plant J, Mueller-Harvey I (2010) Interactions of tea tannins and condensed tannins with proteins. J Pharmaceut Biomed Anal 51:490-495

16. Hagerman AE, Butler LG (1981) The specificity of proanthocyanidin-protein interactions. J Biol Chem 256:4494-4497

17. Soares S, Mateus N, de Freitas V (2007) Interaction of different polyphenols with bovine serum albumin (BSA) and human salivary $\alpha$-amylase (HSA) by fluorescence quenching. J Agric Food Chem 55:6726-6735 
18. Papadopoulou A, Green RJ, Frazier RA (2005) Interaction of flavonoids with bovine serum abumin: A fluorescence quenching study. J Agric Food Chem 53:158-163

19. Lakowicz JR (2006) Principles of fluorescence spectroscopy, 3rd edn. Springer, New York

20. Dueñas M, Estrella I, Hernández T (2004) Occurrence of phenolic compounds in the seed coat and the cotyledon of peas (Pisum sativum L.). Eur Food Res Technol 219:116-123

21. Dueñas M, Sun B, Hernández T, Estrella I, Spranger MI (2003) Proanthocyanidin composition in the seed coat of lentils (Lens culinaris L.). J Agric Food Chem 51:7999-8004

22. Naczk M, Shahidi F (1989) The effect of methanol-ammoniawater treatment on the content of phenolic acids of canola. Food Chem 31:159-164

23. Price ML, Van Scoyoc S, Butler LG (1978) A critical evaluation of the vanillic reaction as an assay for tannin in sorghum grain. J Agric Food Chem 26:1214-1218

24. Karamać M, Kosińska A, Pegg RB (2006) Content of gallic acid in selected plant extracts. Pol J Food Nutr Sci 57:55-58

25. Hames BD (1990) One-dimensional polyacrylamide gel electrophoresis. In: Hames BD, Rickwood D (eds) Gel electrophoresis of proteins. IRL Press, Oxford University Press, Oxford, pp 1-147

26. Bradford MM (1976) A rapid and sensitive method for quantification of microgram quantities of protein utilizing the principle of protein-dye binding. Anal Biochem 72:248-254

27. Hagerman AE, Butler LG (1978) Protein precipitation method for the quantitative determination of tannins. J Agric Food Chem 26:809-812

28. Aparicio-Fernandez X, Yousef GG, Loarca-Pina G, de Mejia E, Lila MA (2005) Characterisation of polyphenolics in the seed coat of black jamapa bean (Phaseolus vulgaris L.). J Agric Food Chem 53:4615-4622

29. Karamać M, Kosińska A, Rybarczyk A, Amarowicz R (2007) Extraction and chromatographic separation of tannin fractions from tannin-rich plant material. Pol J Food Nutr Sci 57:471-474
30. Takahata Y, Ohnishi-Kameyama M, Furuta S, Takahashi M, Suda I (2001) Highly polymerized procyanidins in brown soybean seed coat with a high radical-scavenging activity. J Agric Food Chem 49:5843-5847

31. Amarowicz R, Pegg RB (2008) Legumes as a source of natural antioxidants. Eur J Lipid Sci Technol 110:865-878

32. Naczk M, Amarowicz R, Zadernowski R, Shahidi F (2001) Protein precipitating capacity of condensed tannins of beach pea, canola hulls, evening primrose and faba bean. Food Chem 73:467-471

33. Arfan M, Amin H, Karamać M, Kosińska A, Wiczkowski W, Amarowicz R (2009) Antioxidant activity of phenolic fractions of Mallotus philippinensis bark extract. Czech J Food Sci 27:109-117

34. Beninger CW, Hosfield GL (2003) Antioxidant activity of extracts, condensed tannin fraction, and pure flavonoids from Phaseolus vulgaris L. seed coat color genotypes. J Agric Food Chem 51:7879-7883

35. Utsumi S, Yokoyama Z, Mori T (1980) Comparative studies of subunit compositions of legumins from various cultivars of Vicia faba L. seeds. Agric Biol Chem 44:595-601

36. Wright DJ, Boulter D (1974) Purification and subunit structure of legumin of Vicia faba L. (broad bean). Biochem J 141:413-418

37. Scholz G, Manteuffel R, Müntz K, Rudolph A (1983) Lowmolecular-weight polypeptides of vicilin from Vicia faba L. are products of proteolytic breakdown. Eur J Biochem 132:103-107

38. Naczk M, Oickle D, Pink D, Shahidi F (1996) Protein precipitating capacity of crude canola tannins: effect of $\mathrm{pH}$, tannin and protein concentration. J Agric Food Chem 44:2144-2148

39. Soral-Śmietana M, Świgoń A, Amarowicz R, Sijtsma L (1998) The solubility of trypsin pea protein hydrolysates. Nahrung 42:217-218

40. Gwiazda S, Schwenke KD, Rutkowski A (1980) Isolation and partial characterization of proteins from pea. Nahrung 24:939-950 